TELEGDI ATTILA

\title{
INNOVÁCIÓS LEHETŐSÉGEK A MAGYAR GYORSKORCSOLYÁZÁS MÓDSZERTANÁBAN. A HOSSZÚ TÁVÚ SPORTOLÓFELKÉSZÍTÉSI MODELL ADAPTÁCIÓJÁNAK LEHETŐSÉGEI A HAZAI GYORSKORCSOLYA SPORTÁGAKBAN.
}

\section{INNOVATION POSSIBILITIES IN THE HUNGARIAN SPEED SKATING METHODOLOGY. POSSIBILITIES OF ADAPTATION OF THE LONG - TERM ATHLETE PREPARATION MODEL IN HUNGARIAN SPEED SKATING SPORTS.}

Eszterházy Károly Egyetem, Neveléstudományi Doktori Iskola, Eger

\begin{abstract}
Absztrakt
A Hosszú Távú Sportolófejlesztési Program (LTAD) egyfajta paradigmaváltás a korábban megismert, a versenysportolók felkészülését irányzó törekvésekkel szemben. A program Kanadából indult 2001-ben a magyar származású Balyi Istvántól, mely több országban már kipróbált és jól működő koncepcióként müködik. Magyarországon a gyorskorcsolya sportágainkban 2003-tól módszeresen az LTAD-programra épülő szemléletet, edzéselméletet és módszertant alkalmaztuk saját környezetünkre, amely eredményeképpen a nemzetközi élvonalba kerültünk. A kutatásunk célja annak bemutatása, ahogy az LTAD elveit és módszertanát a rövidpályás gyorskorcsolyázásba bevezettük. Emellett a sportági fejlesztésben megmutatkozó hiányosságok, nehézségek és erősségek, illetve ezen keresztül a jövőkép kerül összevetésre és elemzésre.

Dokumentumelemzés során az LTAD-programot, a Magyar Országos Korcsolyázó Szövetség sportági stratégiáját, négy különböző éves felkészülési programot, azok egy-egy mezociklusának és mikrociklusának edzéstervét, valamint egy-egy napi edzéstervet dolgoztuk fel a kutatásunk aspektusából. Emellett mélyinterjúkat készítettünk a vizsgált dokumentumokat készítő és azok alapján dolgozó utánpótlás és felnőtt korosztály edzőivel ( $N=4)$.
\end{abstract}


Eredményeink alapján elmondható, hogy az LTAD-programot nem minden területen sikerült teljes mértékben megvalósítani, így a sportág továbbfejlődése nem garantált. A mélyinterjúk azt mutatják, hogy a felkészítést jellemzően a hoszszú távú célok irányítják, de vannak jelek még a rövid távú célok alapján történő felkészülésre is. A szülőkkel való együttműködés, a folyamatos kommunikáció, a tudatos fejlesztés hiányossága egyértelműen gátolja az LTAD elveinek és gyakorlatának megvalósítását. Emellett a testnevelés, a közösségi szabadidős sport, a tanulás és az élsport közötti harmonizáció helyenként hiányos.

Egyértelművé vált, hogy hazai rendszerben vannak kihasználatlan lehetőségek. Bízunk abban, hogy ezzel innovatív irányok és módszertan kerülhet a gyorskorcsolyaedző-képzésbe, -továbbképzésbe és egyúttal az edzők mindennapi gyakorlatába is.

Kulcsszavak: LTAD, kommunikáció, innováció, fejlesztés

\section{Abstract}

The Long-Term Athlete Development Program (LTAD) is a kind of paradigm shift from previously known efforts to prepare competitive athletes. The program started in Canada in 2001 from István Balyi of Hungarian origin, which has already been tested and works well in several countries. In Hungary, we have been systematically applying the LTAD program-based approach, training theory and methodology to our own environment in our speed skating sports since 2003 , as a result of which we have become at the international forefront. The aim of our research is to present how we introduced the principles and methodology of LTAD in short track speed skating. In addition, the shortcomings, difficulties and strengths in sports development, and through this the vision, are compared and analyzed.

During the document analysis, we processed the LTAD program, the sports strategy of the Hungarian National Skating Federation, four different annual preparation programs, their training plans for each meso cycle and their microcycle, as well as a daily training plan from the aspect of our research. In addition, in-depth interviews were conducted with youth and adult coaches ( $\mathrm{N}$ $=4$ ) who prepared and worked on the examined documents.

Based on our results, it can be said that the LTAD program was not fully implemented in all areas, so the further development of the sport is not guaranteed. In-depth interviews show that preparation is typically driven by long-term goals, but there are signs even of preparation based on short-term goals. Lack of cooperation with parents, continuous communication, conscious development clearly hinders the implementation of LTAD principles and practices. In addition, harmonization between physical education, community recreation, learning and elite sports is incomplete in some places.It has become clear that there are untapped opportunities in the domestic system. We hope that with this, innovative 
directions and methodologies can be included in the training and further training of speed skating coaches and at the same time in the daily practice of coaches.

Keywords: LTAD, communication, innovation, development

\section{Bevezetés}

Az LTAD (Long-Term Athlet Development), a Hosszú Távú Sportolófejlesztési Program Kanadából indult 2001-ben a magyar származású Balyi Istvántól, mely több országban már kipróbált és jól működő koncepcióként üzemel (Kanada, Ausztrália, Bahrein, Anglia, Skócia, Dél-Afrikai Köztársaság stb.). A program egyfajta paradigmaváltás a korábban megismert, sportolók felkészülését irányzó törekvésekkel szemben. Magyarországon a gyorskorcsolya sportágainkban 2003-tól módszeresen az LTAD-programra épülő edzéselméletet, módszertant és sportpedagógiát adaptáltuk saját környezetünkre, aminek eredményeképpen rövidesen a nemzetközi élvonalba kerültünk rövidpályás gyorskorcsolyázásban.

Az LTAD a sport, a rekreáció, az egészségügy és az oktatás területét összefogva elősegíti hosszú távú sportolófejlesztést egy többlépcsős edzés-, versenyés regenerálódási programon belül. Útmutatást nyújt az egyén sport- és fizikai aktivitásában a csecsemőkorától kezdve a felnőttkor minden fázisán keresztül, valamint hátteret nyújt a hosszú távú sportolófejlődés 10 kulcstényezőjéhez, amelyek az edzés és teljesítmény fejlesztésének legfőbb komponensei. A hosszú távú sportolófejlesztési program felvázolja a sportolók legfontosabb értékeit és alapelveit. A résztvevők szélesebb körü rálátást kapnak az élethosszig tartó sportra - a hosszú távú sportoló fejlődésére, és megtanulják, hogy ennek a programnak a felkarolása hogyan javítja a sport minőségét és a fizikai „írástudást".

A Hosszú Távú Sportolófejlesztési Program egy olyan részletes fejlesztési terv, amelynek általános koncepciója minden sportág környezetére adaptálható, legfőbb ismérve mégis az, hogy az utánpótláskorú versenyzők fejlesztését holisztikus módon közelíti meg. Ezt a szemléletet tükrözi Balyi István egy megállapítása, miszerint „egy nemzet egészsége és jólléte, valamint a nagy sporteseményeken megszerzett érmek csak melléktermékei egy hatékony sportrendszernek".

A témaválasztásunkat indokolta, hogy az LTAD bevezetése sportágainkban komoly előrelépést eredményezett a rendszerszintű gondolkodásban, az összefüggések felismerésében, melyet egyfajta innovációs folyamatként értelmezhetünk az LTAD bevezetésével, hiszen megkezdtük a tudás alkalmazását. Az LTAD iránymutatásait figyelembe véve a felkészülésben alkalmazzuk az új ötleteket, edzésmódszereket, technológiákat, amelyek segítségével magasabb minőséget, értéket hozunk létre, eredményesebbek leszünk. A tudás az innováciő hajtóereje. A tudás a tapasztalat aktív alakításából előálló eredmény (Polányi, 1997).

Az LTAD alapelve a folyamatos jobbításra törekvés, amelyet a japánok egy szóval úgy hívnak, hogy „Kaizen”. A folyamatos jobbításra törekvés biztosítja a tudományos, az edzőszakmai és sportspecifikus innovációkat, tapasztalatokat 
és megfigyeléseket, és a további kutatások terepét is biztosítja. Az LTAD a változás motorjaként észleli és reagál a testnevelésben, a rekreációban történő változásokra, és egyben egy koherens, logikus és könnyen alkalmazható programot kínál minden korosztálynak. A program egyfajta képzési és érzékenyítési lehetőséget kínál a sport, a rekreáció, a fizikai aktivitás és az oktatás érintettjei számára, összekötve a testnevelést, az iskolai sportot, a közösségi rekreációt, az élethosszig tartó aktivitást és az élsportot, egyúttal integrálja a különböző alrendszereket, mely a közös alapelveken és célokon alapul. A fejlődés érdekében minden résztvevőt invitál, bevon a közös gondolkodásba és további fejlesztések elvégzésére a magyar sport érdekében.

Ahhoz, hogy a folyamatos fejlődést biztosítsuk, rendszeresen ellenőriznünk kell, miképpen valósultak meg törekvéseink. A legfontosabb feladataink között kell szerepelnie többek között az optimális életkornak és nemnek megfelelő felkészülés és versenyeztetés biztosításának Borms, 1986). Az edzés- és a versenyprogramok legtöbbször a naptári életkor alapján íródnak, ám a 10-16. életévükben járó sportolók között nagy fejlődésbeli eltérés mutatkozhat (Balyi, Way és Higgs, 2013). A versenynaptárt a biológiai és serdülőkori élettan, a sportfiziológia, a motoros tanulás, a sportpszichológia és a táplálkozástudományi törvények együttes figyelembevételével kell megtervezni és összeállítani (Mujika, Halson, Burke, Balagué és Farrow, 2018). A túlzott versenyeztetés pszichés túlterheléshez vezethet, és egyúttal a felkészülés háttérbe szorítását eredményezi, ami aluledzettséget okozhat hosszú távon (Telegdi, Balyi, és Györgyi, 2020).

További feladataink között szerepel a hosszú távú célok szem előtt tartása a felkészülés során. Sokan állítják, hogy az elit szint eléréséhez minimum 10 évnyi (vagy 10000 óra) gyakorlás szükséges (Ericsson, Charness, Hoffman és Feltovich, 2006). Más vizsgálatok alapján 11-13 év kell az elit atlétáknak ahhoz, hogy a legmagasabb szintű teljesítményt elérjék (Gibbons, Hill-McConnell, Forster és Moore, 2002). A lényeges azonban az, hogy nem lehet lerövidíteni a kiválósághoz vezető időtartamot, a résztvevők fejlesztése hosszú folyamat, hozzávetőlegesen egy évtized vagy még ennél is több idő alatt lehet eljutni a nemzetközi szintre. Ez hosszú idő, de a rövid távú céloknak (eredménykényszer, bajnoki címek) nem szabad felülírniuk a sportolók hosszú távú fejlesztését (Viru, 1995).

Rendkívül fontos a program hatékonyságának biztosítása szempontjából a szülők partnerként történő bevonása a gyerekek képzésébe, a megfelelő rendszeres kommunikáció, egyszóval a szülői edukáció kialakítása és fenntartása (Balyi, Géczi, Bognár, Bartha, 2016). A sportoló-szülő-edző sportháromszög két csúcsának, a szülőnek és az edzőnek a kölcsönös kommunikációja elengedhetetlen fontosságú. A szülők ebben a rendszerben összekötő szereppel is rendelkeznek (Széplaki, Bachmann, Simon, Kovács, Gyömbér és Smohai, 2017). Korábbi kutatások egyértelműen bizonyítják a család, elsősorban a szülők erőteljes befolyásoló szerepét a fiatalok sportolási szokásainak kialakításában, a sportágválasztásban, a felkészülés folyamatában, majd a versenyzés során elért sikerekben, esetleg kudarcokban is (Bognár, Bicsérdy, Géczi, 2006; Fügedi, Bognár, Kovács, 2019). 
További feladat a versenysport, a testnevelés és szabadidősport összehangolása. Egy jól tervezett edzésprogramban figyelembe kell venni az iskolai terheléseket is, melyekbe beletartoznak a tanulási terhelések és a vizsgák hatása is. Ha lehetséges, akkor az edzőtáborokat és a versenyre való utazásokat összhangba kell hozni az iskolai kötelezettségekkel. A mindennapos testnevelési órák, az egyéb sporteseményeken történő versenyeztetés és annak terhelése meghatározza, befolyásolja a terhelésdinamikát. A gyerekek különböző sporteseményeken történő indítása előtt fontos, hogy kommunikáljon az edző és a testnevelő. A kommunikáció rendkívül fontos, mert a különböző sportágakban egyszerre sportoló gyerekeknél a különböző edzéshatások interferenciát okozhatnak. (Telegdi, Balyi és Györgyi, 2020)

A megfelelő életkorban történő sportági specializáció kialakítása is egy fontos kritériumnak tekintendő. A korai specializáció a késői vagy nagyon késői specializációt igénylő sportágakban a következőket okozza:

- egyoldalú, sportágspecifikus felkészítés,

- az agilitás, az egyensúly, a koordinációs képességek és a gyorsaság hiánya; az alapvető mozgáskészségek, mozgásügyesség és sportkészségek, sportügyesség nem megfelelő szintje,

- túlterheléses sérülékenység,

- korai kiégés,

- lemorzsolódás.

(Telegdi, Balyi és Györgyi, 2020)

\section{A kutatás célja}

A kutatásunk célja rávilágítani, hogy az LTAD által megfogalmazott legfőbb célkitűzéseket, valamint a sportban fellehető legfőbb hiányosságokat sikerült-e a hazai rövidpályás gyorskorcsolya sportágban megszüntetni, és ha nem, akkor ez milyen okokra vezethető vissza.

\section{A kutatás bemutatása}

A kutatás során az utánpótláskorú versenyzők edzésterveit $(N=4)$ és edzőik $(\mathrm{N}=4)$ nézeteit vizsgáljuk a strukturált interjú módszerével a junior D-C (11-15 éves) és junior B-A (15-20 éves) korosztályok vonatkozásában. A vizsgálat során négy csoportot vizsgálunk, amelyek közül mindegyik csoportban a junior versenyzők szempontjából végzünk kutatásokat. A négy csoport két egyesületből (tagszervezet), egy junior válogatott és egy felnőtt válogatott (amelyben junior versenyzők is dolgoznak) csoportból áll.

A kutatás során a következő dokumentumelemzéseket és mélyinterjúkat végeztük el:

I. Az LTAD-program vizsgálata. 
II. A Magyar Országos Korcsolyázó Szövetség Sportági Stratégiájának vizsgálata.

III. A felnőtt válogatott, a junior válogatott és két tagszervezet 2019-2020-as szezonbeli éves felkészülési programjának, mezociklusának, mikrociklusának és egy napi edzésének vizsgálata.

IV. Mélyinterjú a vizsgált dokumentumokat készítő és azok alapján dolgozó két utánpótlásklub-edzővel (KE1, KE2), egy junior válogatott edzővel (JVE) és egy felnőtt válogatott edzővel (FVE) készült, aki szintén foglalkozik junior korosztályú versenyzővel a felnőtt válogatott keretben.

\section{Az LTAD-program dokumentumelemzés vizsgálata}

A kutatás során dokumentumelemzés módszerével először az LTAD-programot vizsgáltuk meg. A program hátteret nyújt a hosszú távú sportolófejlődés 10 kulcstényezőjéhez, amelyek az edzés és teljesítmény, valamint e kettő optimális környezetének kialakításához szükséges feltételek legfőbb komponensei. Ezen kulcstényezők figyelembevétele meghatározó a hosszú távú sportolófejlesztés optimális kialakítása során. Ez a $5+5$ tényező a következő:

Az 5 motoros képesség:

1. Erő

2. Állóképesség

3. Gyorsaság

4. Ügyesség

5. Hajlékonyság, izomlazaság

Valamint kiegészítő 5 feltétel:

6. Alkat/termet (differenciált képzéssel összefüggő szempont)

7. Iskolai körülmények (iskolai terhelés mint befolyásoló tényező)

8. Pszichológia (mentális egészség)

9. Fenntarthatóság (regeneráció)

10. Szociokultúra (sport által kialakuló szocializációs készségek)

Az LTAD-program felsorol egy sor a magyar sportra is jellemző hiányosságot és azok várható következményeit, amelyek megakadályozzák a fejlődést, akár a versenysportról, akár a rekreációról van szó. Ezek közül kiemeltünk néhány meghatározó hiányosságot, amelyeket a kutatásunk során alapvető szempontként használunk mind a dokumentumelemzés, mind az interjúk során.

Az LTAD-programból kiemelve a mai nemzetközi sportban megtalálható hiányosságokat vizsgáljuk, mint például a fiatal sportolók túlversenyeztetése és egyben aluledzése vagy a felnőtt edzéstervek és versenyeztetési tervek alkalmazása junior korú versenyzők esetében. Hasonlóképpen vizsgáljuk, hogy vajon fiúk számára írt edzéseket alkalmaznak-e lányoknál, valamint hogy a felkészítést elsősorban a rövid távú célok irányítják-e (győzelem, bajnoki cím), és nem a hosszú távú teljességre törekvés, illetve hogy a szülők informálása, képzése, fejlesztése megtörténik-e a sportolók hosszú távú felkészítésének szempontjából (táplálkozás, regeneráció, érési jellemzők és pszichoszociális fejlesztés). Emellett vizsgáljuk, hogy van-e összhang a testnevelés, a közösségi 
szabadidős sport és az élsport programjai között, és hogy a sportág túl korán specializálja-e a sportolókat azért, hogy bevonzza és megtartsa őket a sportág számára.

\section{A Magyar Országos Korcsolyázó Szövetség Sportági Stratégiájának vizsgálata}

A dokumentum vizsgálata során azt elemeztük, hogy az LTAD-ben szereplő hiányosságok elkerülésére vonatkozóan a szövetségi stratégia tartalmaz-e iránymutatásokat, illetve utalásokat, amellyel az LTAD elveit erősíti.

1. Túlversenyeztetés, aluledzés jellemző a sportágra?

A MOKSZ Stratégia nem ad iránymutatást a különböző korosztályok versenyeztetését illetően. A stratégiában a junior és felnőtt korosztályok számára a versenynaptárban rögzített időpontokban versenylehetőségeket biztosít a szövetség, és a szakma dönti el a célversenyek kivételével, hogy mely versenyzőjét hol és a szezonon belül hány alkalommal versenyezteti.

Az edzésekre vonatkozóan azok számával kapcsolatban nem tartalmaz utalást a stratégia.

2. Felnőtt versenyrendszer alkalmazása fiatal sportolóknál jellemző a sportágra?

A gyorskorcsolya sportversenyeinek felsorolásánál minden versenynél meg van adva a naptári életkor alapján meghatározott korosztály és az életkori sajátosságoknak megfelelő versenyprogram (pl.: koordinációs képességfejlesztést célzó gyakorlatsorok), illetve versenytáv.

3. Sportágunkban felnőtt edzésprogramot alkalmaznak fiatal sportolóknál?

4. Fiúk számára írt edzéseket alkalmaznak lányoknál a sportágban?

5. A sportágban a felkészítést elsősorban a rövid távú célok irányítják (győzelem, bajnoki cím) és nem a hosszú távú teljességre törekvés?

6. Jellemző a sportágra a szülők informálása, képzése, fejlesztése a sportolók hosszú távú felkészítésének szempontjából (táplálkozás, regeneráció, érési jellemzők és pszichoszociális fejlesztés)?

A 3-6. pontokra vonatkozóan nincs utalás a sportági stratégiában.

7. Összhang van a testnevelés, a közösségi szabadidős sport és az élsport programjai között?

A diáksport szövetséggel szoros a szövetség együttműködése, a diákolimpia versenyeit a hazai versenynaptárba a többi korosztályos verseny figyelembevételével emelik be. A szövetség közösségi és szabadidős tevékenységei szövetségi rendezés alatt müködnek, Így azok a rendszerben összhangban vannak. A közoktatási intézményekkel, testnevelőkkel, iskolákkal szoros a szövetség kapcsolata, így az élsporttal összhangban van az iskolai fejlesztés.

8. A sportág túl korán specializálja a sportolókat azért, hogy bevonzza és megtartsa őket a sportáguk számára?

Erre vonatkozóan nincs utalás a stratégiában. 
III. A vizsgált csoportok 2019-2020-as szezonjában az éves felkészülési program dokumentumainak vizsgálati eredményei (egy mezociklus, egy mikrociklus és egy napi edzés), valamint a strukturált interjúk eredményei

1. Jellemző, hogy fiatal sportolókat túlversenyeztetik és egyben aluledzik.

A túlversenyeztetés és aluledzés vonatkozásában az éves felkészülési tervek dokumentumelemzése a meghatározó. Az 1. számú táblázat a junior C-D korcsoport és az A-B korcsoport felkészülési és célversenyeinek összesített számát tartalmazza egy versenyszezonra vonatkozóan.

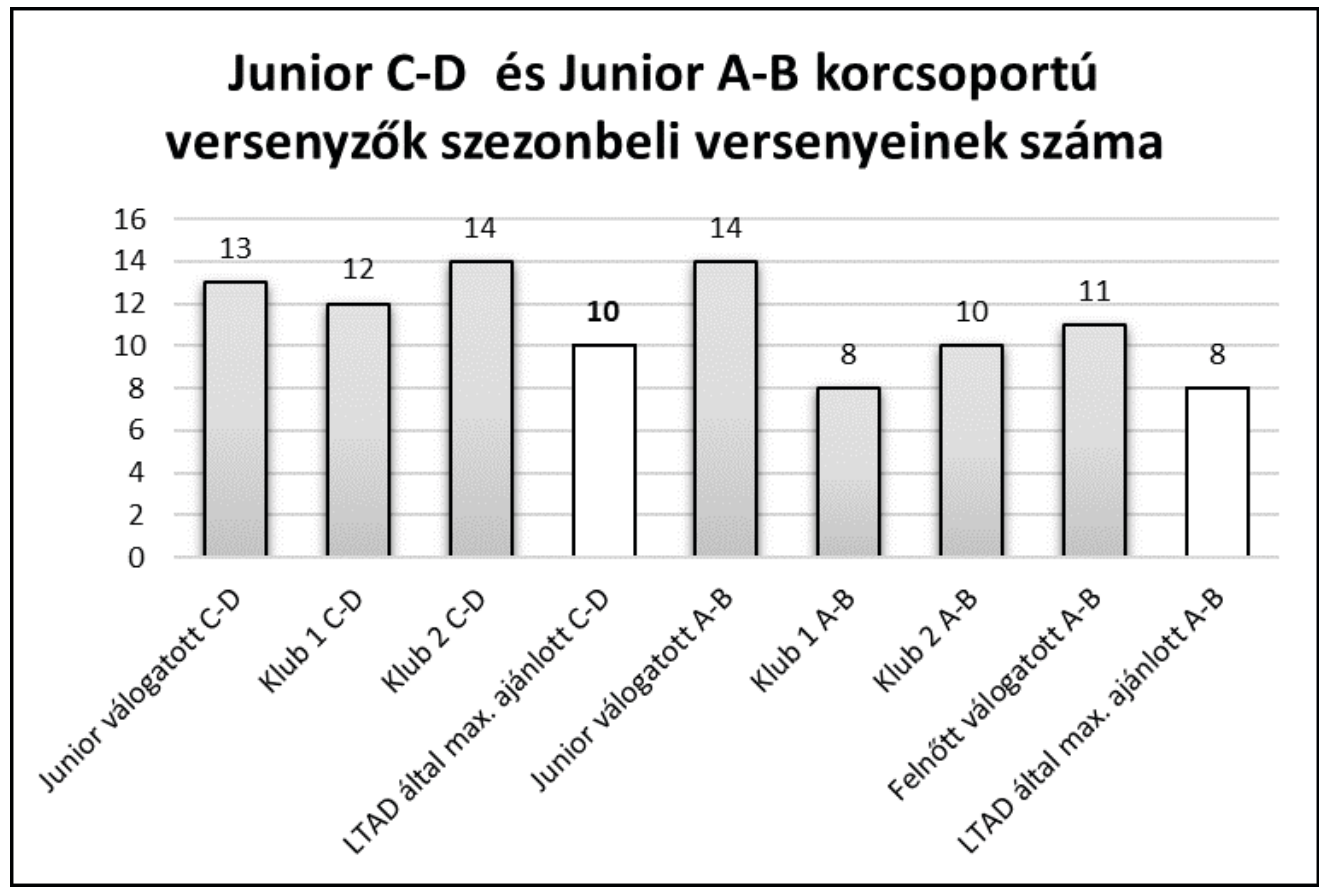

1. táblázat: A junior C-D és A-B korcsoportú versenyzők versenyszezonon belül tervezett versenyeinek száma és az LTAD által javasolt versenyek száma

A számadatok alapján kiderült, hogy szeptembertől áprilisig 8 hónap a versenyszezon hossza. A versenyek száma a korosztályos hosszú távú felkészítés szempontjából sok. Az LTAD ajánlása szerint maximum 10 verseny/szezon ajánlott a junior C-D korosztálynak, míg maximum 8 verseny a junior A-B korosztálynak. Elmondható, hogy nagyrészt túl vannak versenyeztetve a vizsgált versenyzők.

Az interjúk alapján az edzők nem tartják magasnak a versenyek számát. Idézünk egy klubedzőt:

„Alkalmazkodom a versenynaptárhoz, igyekszem minden lehetőséget megragadni a gyerekek versenyzésére." KE1

2. Felnőtt versenyrendszer alkalmazása fiatal sportolóknál

A versenyrendszer vonatkozásában a szövetség korcsoportos versenyeket rendez, melyekre a klubok edzői szabadon nevezhetik a versenyzőiket. A versenyek 
programja és távjai az életkori sajátosságoknak megfelelően a szövetség versenybizottsága által és a Nemzetközi Korcsolyázó Szövetség által van meghatározva, ami megegyezik az LTAD iránymutatásával, tehát nem felnőtt versenyrendszert alkalmaznak fiatal sportolóknál. Az edzőkkel végzett interjúk szerint azonban kisebb módosításokra azért szükség lenne az életkorok és versenytávok összehangolásában. Az egyik klub edzője ezt így fogalmazta meg:

„A hazai és nemzetközi versenyszabályzat jól szabályozza a kérdést, azonban szerintem lehetnének kissé rövidebbek a távok a junior C-D korosztályban, ami jobban illeszkedne az életkori sajátosságokhoz és a szenzitiv időszakokhoz egyaránt." KE1

3. Felnőtt edzésprogramot alkalmaznak fiatal sportolóknál.

Erre vonatkozóan az interjúkból egyértelműen kiderült, hogy csak a felnőtt válogatottnál alkalmaznak felnőtt edzésprogramot fiatal versenyzőknél. Ezzel kapcsolatban a felnőtt válogatott edző a következőt nyilatkozta:

„A junior korú versenyzőknek jót tesz, ha a felnőtt példaképeikkel együtt edzenek. A korosztályból fakadó különbségekre, az egyéni reakciókra figyelünk, differenciálunk, de nagyon gyorsan adaptálják a juniorok ezen a szinten már a felnőttek számára kiírt munkát." FVE

A junior válogatott edzője és egy klubedző szerint jellemző a folyamat, náluk ugyan nem fordul elő, de máshol klubszinten észlelhető. Idézzük az egyik junior válogatott edzőt:

„Mi igyekszünk testre szabni, a korosztályos specifikumoknak, szenzitív időszakoknak megfelelöen differenciálni a képzést, de ezt klubszinten már nem látom, hogy mindenütt megvalósulna."JVE

Az éves felkészülési programok mezociklusainak, mikrociklusainak és a napi edzésnek a dokumentumvizsgálatai alapján a felnőtt válogatott programjaiban nem találtunk differenciálást a junior A-B korosztályú 18-20 éves versenyzők és a felnőtt versenyzők edzésprogramjában. Versenyeztetés szempontjából ugyanabban a versenyrendszerben szerepelnek, de például a szenzitív időszakok és az LTAD elvei szerint a junior versenyzőknek még differenciált felkészülést kellene végezniük. Tehát elmondhatjuk, hogy a felnőtt válogatottban dolgozó junior A-B korú versenyzők felnőtt edzésprogramot végeznek junior koruk ellenére.

4. Fiúk számára írt edzéseket alkalmaznak lányoknál.

Dokumentumelemzéseink során az éves felkészülési programok, a mezociklusok, mikrociklusok és napi edzés vizsgálatai alapján megállapítottuk, hogy mindegyik vizsgált csoportban differenciált edzést folytatnak a fiúk, illetve a lányok. Ezt erősítették meg az interjúink is, amelyek között az egyik klubedző a következőt mondta:

"Én nagy hangsúlyt helyezek a differenciált képzésre, és nemcsak az életkor, hanem a nemek tekintetében is." KE1 
A strukturált interjúk alapján is megállapítottuk, hogy differenciált edzés jellemzi a lányok és fiúk felkészítését.

5. A felkészítést elsősorban a rövid távú célok irányítják (győzelem, bajnoki cím), és nem a hosszú távú teljességre törekvés.

Ez az éves felkészülési programok, a mezociklusok, mikrociklusok és egy napi edzés dokumentumvizsgálatai alapján nem derült ki, azonban mindegyik edző az interjúk során a hosszú távú célokat tartotta meghatározónak a felkészítés során. Idézzük az egyik klubedzőt:

"Én és a kollégáim a klubunkban a válogatottságra és távoli célként az olimpiára készítjük a gyerekeket, nem az azonnali győzelmekre. Ha ezt a célt nem is mindenki éri el, de addig egészségre nevelünk, és tartalmas időtöltést biztosítunk számukra." KE2

Két edző szerint néhány klubban jellemző a rövid távú célok alapján történő felkészülés, de mindketten az okok között a szülői nyomást emelték ki. Idézzük az egyik edzőt, a felnőtt válogatott edzőjét:

„Szerintem igyekeznek az edzők hosszú tóvú célokat kitüzni, de ettől néha a szülök nyomása az azonnali siker érdekében eltéríti őket." FVE

A vizsgált edzők mindegyike hosszú távú célokat tűzött ki a felkészülés szempontjából, amely megegyezik az LTAD céljával.

6. A szülők informálása, képzése, fejlesztése nem történik meg a sportolók hosszú távú felkészítésének szempontjából (táplálkozás, regeneráció, érési jellemzők és pszichoszociális fejlesztés).

Az éves felkészülési programok, a mezociklusok, mikrociklusok és a napi edzés dokumentumvizsgálatai alapján kiderült, hogy a klubok, de még a junior válogatott vezetése is készít a szülők számára összefoglaló programokat arról, hogy a gyerekek elkövetkező időszakban mit fognak csinálni, hogy megfelelő információkkal rendelkezzenek a szülők gyermekeik elfoglaltságait illetően. Ezt megerősítették az interjúk is, amelyek közül idézzük az egyik junior válogatott edzőt és az egyik klubedzőt:

„Minden héten már szombaton megkapják a szülők a gyermekük következő heti programját, melyhez az éves program is csatolva van, hogy tervezni tudjanak. Természetesen szakmailag nem olyan részletes, de szerintem eléggé informatív." JVE

„A szülők edukációjára helyezünk hangsúlyt, például mit egyenek a gyerekek, mennyit pihenjenek, hogy öltöztessék fel öket, hogyan segíthetik gyermeküket stb. Ezekre az oktatásokra a szülői értekezleteken és személyes konzultációkon kerítünk sort." KE2

7. Nincs összhang a testnevelés, a közösségi szabadidős sport és az élsport programjai között. 
Ez nem derül ki az éves felkészülési programok, a mezociklusok, mikrociklusok és egy napi edzés dokumentumvizsgálatai alapján. Az interjúkból azonban az derült ki, hogy a gyerekek többsége sportiskolába jár, így jó az összhang a testnevelés, a közösségi szabadidős sport és az élsport programjai között. Az egyik klubedző ezt így foglalta össze:

„A versenyzőim nagy része sportiskolába jár, így sokkal könnyebb összeegyeztetni az edzéseket, versenyeket és a tanulást. Jellemzőbbek a nehézségek a nem sportiskolába járó versenyzőink esetében." KE2

8. Néhány sportág túl korán specializálja a sportolókat azért, hogy bevonzza és megtartsa őket a sportáguk számára.

Ez nem derül ki az éves felkészülési programok, a mezociklusok, mikrociklusok és egy napi edzés dokumentumvizsgálatai alapján, és az interjúkból az derült ki, hogy nem törekszenek a korai specializációra az edzők. Idézzük az egyik klubedzőt:

„Szerintem ez a mi sportágunkra nem jellemző, inkább mi érzékeljük más sportágaknál. Mi igyekszünk az LTAD által meghatározott általános képességfejlesztésre törekedni, és például hagyjuk, hogy más sportágakban is kipróbálják magukat." KE1

\section{Megbeszélés}

A kutatásunk alapján a túlversenyeztetés az edzői vélemények alapján nem jellemző, azonban az éves edzéstervek mást mutatnak. Mindenesetre a túlversenyeztetés problémaköre nem alábecsülendő, hiszen komoly veszélyforrást jelent a hosszú távú felkészülés során, ami az aluledzéssel is párosulhat, és ez már komolyabb problémaként jelentkezik az edzőknél. Lénárt (2019) szerint a klub- és szövetségi érdekek sajnos sokszor nem az optimális versenyeztetés irányába billentik a mérleget.

A felnőtt versenyrendszer alkalmazása fiatal sportolóknál nem jellemző, azonban az életkori sajátosságok vonatkozásában még finomításra szorulnak a versenytávok, annak ellenére, hogy a nemzetközi és hazai szövetség egyaránt figyelmet fordít rá.

A felnőtt edzésprogramok fiatalokkal történő alkalmazását illetően az eredmények alapján megállapítottuk, hogy folyamatos monitorozásra szorul, hiszen a hosszú távú felkészülés folyamatának egyik legfontosabb mérföldkövéről beszélünk, amely a versenyzők folyamatos fejlődésének egyik meghatározó eleme. Nagy, Sós és Ökrös (2012) korábbi úszókon végzett vizsgálatai alapján megállapították, hogy a magyarországi úszók a rendszeres edzések megkezdésétől egészen 12-13 éves korig testi és szellemi érettségükhöz képest jóval nagyobb terhelésnek vannak kitéve.

A fiúk számára írt edzések alkalmazása lányoknál nem jellemző sportágunkban, ami az LTAD elvárásainak megfelel. 
A felkészítést a hosszú távú teljességre törekvés jellemzi, a vizsgálatba bevont edzők eredményei alapján erre a megállapításra jutottunk, azonban a vizsgálatba bevont edzők a környezetükben dolgozó többi edző esetében azért tapasztalják a rövid távú célokra épülő felkészülés jegyeit, melyet alapvetően néhány edző tevékenysége és nagyobbrészt a szülői megnyilvánulások tükröznek. A szülői edukáció hiánya ennél a problémakörnél is markánsan megjelenik éppúgy, mint a szülői tájékoztatás, fejlesztés hiányossága, ami egyértelmúen destruktív folyamatként jelentkezik az LTAD hosszú távú céljainak megfogalmazása és a hosszú távú felkészülés szempontjából.

A testnevelés, a közösségi szabadidős sport, a tanulás és az élsport közötti harmonizáció szövetségi szinten, valamint klubszinten egyaránt megoldottnak látszik, azonban ez elsősorban a sportiskolákkal kapcsolatban áll fenn, a nem sportiskolák esetében még felmerülnek a témában problémák. Az LTAD ajánlásának megfelelően a sportszervezeteknek és az oktatás egyéb résztvevőinek folyamatos szoros együttműködésre van szüksége az egységes és hatékony hoszszú távú sportolófelkészítés programjának zökkenőmentes megvalósításához.

Az LTAD kanadai, szülők számára készült információs anyagából (LTAD information for parents) kiderül, hogy az edzéstervek nagy része a legtöbb sportágban a korai specializációt, valamint a korai intenzív edzést hangoztatja, csakhogy ez nem segíti a gyermeket abban, hogy a lehető legjobb lehessen. Ennek jeleit nem találtuk a vizsgálataink során. A korai specializáció jeleivel nem találkoztunk vizsgálataink során. A vizsgálataink összefoglalóját az 1. számú ábra mutatja.

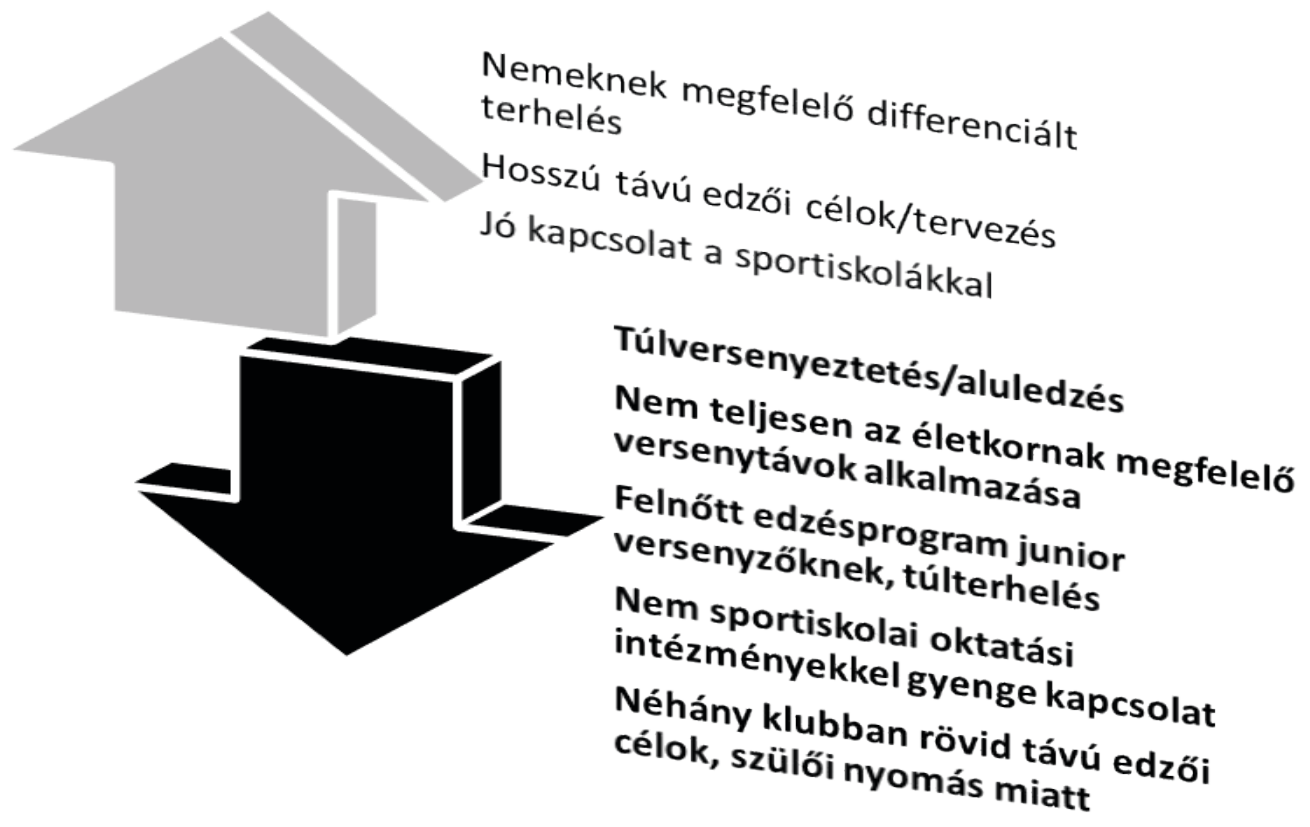

1. ábra: A vizsgálataink során alkalmazott szempontrendszer alapján az LTAD-program megvalósult és még hiányos területei 
További kutatások elvégzését látjuk szükségesnek, hogy teljes képet kapjunk A Hosszú Távú Sportolófejlesztési Program működésének és hatásmechanizmusának vonatkozásában azáltal, hogy a versenyzőket a szülőket és sportvezetőket is bevonjuk a kutatásokba.

A gyorskorcsolya sportágakban bevezetésre került LTAD-programmal elért eredmények további folytatásához a hiányosságok megszüntetésére van szükség, amelyekre a jelen kutatás is rámutatott. Az LTAD rendszere csak egy keretet ad, amelyben a sportágaknak lehetőségük van a folyamatos innovációra, de csak abban az esetben, ha az eredményesség és a sikerek mellett észreveszik a szakemberek a hiányosságokat is. A kutatásunkat is az a cél vezérelte, hogy a hiányosságok feltérképezését követően megtaláljuk azokat a módszereket, amelyekkel egy folyamatos szakmai megújulást biztosíthatunk úgy, hogy reagálunk a kor igényeire és a folyton változó társadalmi kihívásokra.

\section{FELHASZNÁLT IRODALOM}

Balyi István, Géczi Gábor, Bognár József, Bartha Csaba (2016). Hosszútávú sportoló fejlesztési program. A Magyar Olimpiai Bizottság kiadványa, Budapest, Magyarország : Magyar Olimpiai Bizottság (MOB).

Balyi, I., Way, R., \& Higgs, C. (2013). Long-Term Athlete Development. Champaign, IL: Human Kinetics. https://doi.org/10.5040/9781492596318

Bognár J., Bicsérdy G., Géczi G. (2006). A szülők szerepe a sporttehetséggondozásban. Kalotagathia, 1-2.sz., A Magyar Testnevelési Egyetem Közleményei, Budapest, 86-95.p.

Borms J. (1986). The child and exercise: An overview. Journal of Sport Sciences, 4, 3-20. https://doi.org/10.1080/02640418608732093

Fügedi, B., Bognár, J., Kovács T., L. (2019). A szülői minta szerepe a sportolási szokásokban és a testnevelés megítélésében. Acta Universitatis De Carolo Eszterházy Nominatae: Sectio Sport, 46, 47-55.p. https://doi.org/10.33040/ActaUnivEszterhazySport.2019.1.47

Gyömbér, N., Kovács, K., Imre, T. Zs., Lénárt, Á., Menczel, Zs. (2019). Fejben dől el. Budapest, Noran Libro Kft., 4-13.

Mujika, I., Halson, S., Burke, L.M., Balagué, G., Farrow, D. (2018). An integrated multifactional approach to periodization for optimal performance in induvidual and team sports. International Journal of Sports Physiology and Performance, 2018, 13, 538-561. https://doi.org/10.1123/ijspp.2018-0093

Nagy, N., Sós, Cs., Ökrös, Cs. (2012). Ellentmondások a fiatalkorú úszók felkészítésében. Magyar Edző, Bp. 2012/2, 17-19.

Polányi Mihály (1997b). Az ember tudománya. In Polányi Mihály: Tudomány és ember, Argumentum, Bp.

Széplaki, A., Bachmann, P., Simon, J., Kovács, K., Gyömbér, N., Smohai, M. (2017). „Kutatás közben", A 7-13 éves sportoló gyerekek szüleivel kapcsolatos 
Kétszempontú Sportolói Támogatás Kérdőívcsomag magyar nyelvú bemutatója. Alkalmazott pszichológia 2017.17(1) 61-75.

Telegdy, A., Balyi, I. (2017). A korcsolyasport hosszútávú fejlesztési programja. Összefoglaló. Magyar Országos Korcsolyázó Szövetség kiadványa. Budapest.

Telegdi, A., Balyi, I., Györgyi, J.(2020). A gyorskorcsolyasportok hosszútávú fejlesztési programja. Magyar Országos Korcsolyázó Szövetség kiadványa. Budapest.

Way, R., Balyi, I., Higgs, C., Bluehand, M., Cardinal, C., Higgs, C., Narris, S.,Grave, J. (2007). A sport parent's guide. In Canadian sport for life: Long-term athlete development. Canadian sport centres. Ottawa.

\section{Szerző:}

Telegdi Attila

a.telegdi@gmail.com

Eszterházy Károly Egyetem, Neveléstudományi Doktori Iskola, Eger 